\title{
MOTIVATION IN LANGUAGE: THE CASE OF METONYMICALLY MOTIVATED INNOVATIVE NOUNS IN CHILDREN'S SPEECH*
}

\author{
Ewa Konieczna \& Grzegorz A. Kleparski**
}

\begin{abstract}
The aim of this paper is to provide partial evidence that a great many neologisms in children's speech are metonymically motivated. For our purposes we shall rely basically on the language corpus gathered in the course of longitudinal studies carried out during the years 2000-2002, concentrating on innovative nouns formed by English-speaking and Polish children. Apart from this, we will provide selected examples of lexical innovations drawn from Eve V. Clark's language data (Clark 1993). However, before the discussion commences, let us briefly outline the issue of motivation in language in order to provide a broader background for the investigations to follow.
\end{abstract}

Keywords: Motivation, metonymy, innovative nominalisation, perspectivisation, apperception

Resumen: El objetivo de este artículo es demostrar de forma parcial que muchos de los neologismos en el habla de los niños se deben a una motivación metonímica. Para ello nos basaremos básicamente en un corpus del lenguaje recogido a través de una serie de estudios longitudinales llevados a cabo durante los años 2000-2002, centrados en sustantivos innovadores utilizados por niños de habla inglesa y polaca. Además, ofreceremos ejemplos seleccionados de innovaciones léxicas extraídos de datos lingüísticos utilizados por Eve V. Clark (Clark, 1993). También haremos un resumen acerca de la motivación relacionada con el aprendizaje de una lengua para contribuir a ampliar el estado de la cuestión de cara a investigaciones futuras.

Palabras clave: Motivación, metonimia, nominalización innovativa, perspectivización, apercepción

\section{MOTIVATION IN LANGUAGE}

To start with, the notion of motivation is usually contrasted with that of arbitrariness. Paradoxically, it was Ferdinand de Saussure, who put forward the principle of the arbitrariness of the linguistic sign, that may be said to have pioneered the study of motivation in language: "There is no language in which nothing is motivated, and our definition makes it impossible to conceive of a language in which everything is motivated. Between the two extremes -a minimum of organisation and a minimum of arbitrariness- we find all possible

Date of reception: December 2005

Date of acceptance and final version: October 2006

** Ewa Konieczna is senior lecturer, Department of English, The University of Rzeszów, Poland; $\square$ eakon@poczta.onet.pl; Grzegorz A. Kleparski is associate professor, Department of English, The University of Rzeszów, Poland; $₫$ gak@univ.rzeszow.pl. 
varieties" (Saussure 1916: 133). Nevertheless, de Saussure's approach to motivation differs greatly from modern cognitive theories, because the Swiss linguist views motivation as a limiting case of arbitrariness, whereas cognitive linguists tend to regard motivation as the norm and view arbitrariness as the last resort (Lakoff 1987). E.g., Heine (1997: 3) argues that since "human behaviour is not arbitrary but [...] driven by motivation", language structure, which is a product of human behaviour, "must also be motivated".

Recently, a wide variety of theoretical standpoints on the issue of motivation have been adopted $^{1}$ and - therefore - there is no definitional consensus as to this notion. As Radden and Panther (2004) have recently observed, each of these approaches contains the same important elements, that is non-arbitrary relationship between the form and meaning, iconicity, salience and metonymy. According to Lakoff (1987: 107, 148), ideally all these elements need to be integrated into a unified theory of motivation. Such an attempt was undertaken by Radden and Panther (2004) who have proposed that "A linguistic unit, i.e. target (form and/or content) is motivated if some of its properties are shaped by a linguistic source (form and/or content) and language-independent factors". For the purpose of our considerations we intend to adopt this definition because - apart from its universality - it is also quite comprehensive, as it is capable of embodying several aspects of motivation both of a linguistic and extra-linguistic nature.

\subsection{Language-dependent and language-independent motivational factors}

First of all, we intend to discuss language-dependent factors, i.e. source and target. Source is considered to be a basis serving as a potential trigger for a motivational process to operate on, i.e. the form and/or the content of a linguistic unit. Secondly, target, which may again become the form and/or the content of a linguistic unit, is understood as the final stage of a motivational process. For the purpose of our discussion we shall limit our considerations to the form, i.e. target that is motivated by the content, i.e. source, which is the most typical kind of motivation in the language, also as far as the child language is concerned. ${ }^{2}$ Thus, for example, an innovative English noun bear-son ${ }^{3}$ is an example of the coinage in which the content motivates the form, i.e. the message the child wants to express directly influences the morphological shape of the neologism. In other words, the fact that a child wants to express the meaning 'the bear who is somebody's son' leads to the formation of the root compound bear-son. ${ }^{4}$ Consequently, the content of the source shapes the form of the target.

\footnotetext{
${ }^{1}$ See e.g. Hiraga (1994: 3), Haiman (1980,1985), Geeraerts (2002), Lakoff (1987), and Beitel, Gibbs and Sanders (1997: 243).

2 According to Radden and Panther (2004), there are four basic semiotic relations that may be exploited in motivation:

1. a content may motivate a form, as in iconicity,

2. a form may motivate a content, as in folk etymology,

3. a content may motivate another content, as in polysemy,

4. a form may motivate another form, as in phonological change.

${ }^{3}$ Unless another source has been given, all the innovative nouns quoted in this article come from our own language corpus.

${ }^{4}$ Despite the existence of the $\mathrm{N}$ (Modifier) + N (Head) constructional schema afforded by the grammar, the compounds of this type are still regarded as innovative by the researchers of the first language
}

Odisea, $\mathrm{n}^{\circ} 7$, ISSN 1578-3820, 2006, 103-117 
As far as language-independent factors are concerned, Radden and Panther (2004) propose that these are extra-linguistic motivational factors, such as ecological motivation, perceptual motivation, communicative motivation, and others. ${ }^{5}$ At this point let us focus our attention on these language independent factors, one by one, and then an attempt will be made to show that they trigger the formation of coinages in children's speech. Although we are of the opinion that it is metonymy that is largely responsible for the emergence of neologisms in children's speech, there is no denying that motivational factors usually do not function in isolation but they tend either to apply jointly or to compete with one another. Therefore, in the following section we shall focus on extra-linguistic motivational factors with a view to showing the way in which they spur the formation of innovative words in children's speech.

To begin with, let us concentrate on the so-called ecological motivation. Ecological motivation is perceived as the motivation of a linguistic unit due to its place, or ecological niche within a system. In the realm of linguistics, the terms ecology and ecological niche have been introduced by Lakoff (1987: 487). In short, the notion of ecology proposes that a linguistic system contains slots, or, in other words, niches that are to be filled with linguistic units. Relating this concept to children's speech, it is evident that ecological motivation may be regarded as the initial trigger for the formation of numerous coinages because children feel the constant to need to name things contained within their closest environment for which they do not know the relevant names, as they have not acquired them yet. In this sense the language of children abounds in slots that need to be filled. Therefore, we are entitled to say that ecological motivation constitutes the original stimulus for the coinages formation.

Another kind of motivation that plays a key role in the creation if lexical innovations in the language of children is perceptual motivation. As already noticed by Kant, we see things not as they are but as we are (Kant 2001). This means that our perception of the world is inseparable from our experience and cognition. According to Lakoff (1987), the principles of perception enable us to dispose of irrelevant information, supply missing information, and, in this way, structure the sensory stimuli into a meaningful gestalt. Obviously, many of the principles that are responsible for the structuring of perception also motivate language structure. These are attention to salience, recognition of similarity and viewing arrangement. ${ }^{6}$

As far as salience in the formation of neologisms is concerned, it is undoubtedly of cognitive nature. ${ }^{7}$ By this we mean that children are particularly sensitive to the concepts that the word expresses which are salient from the cognitive point of view. For example, from the coinage plate egg (Clark 1993) meant to denote 'a fried egg' we may infer that for

acquisition (c.f. Clark 1993) as, in fact, they lead to the formation of structures non-existent in adult language, which opts for conventional expressions with a view to naming the same phenomenon (for details in this respect the subsection devoted to the motivation in the formation of innovative compounds should be consulted)

${ }^{5}$ In this paper, our intention is to discuss only these types of motivation that are important for the scope of our considerations. For a complete list of all the types of motivation see Radden and Panther (2004). ${ }^{6}$ Since viewing arrangement is not of primary importance for our discussion of children's neologisms, we shall not on this issue here. Viewing arrangement has been extensively studied e.g. by Langacker (1987). 
the child the most salient feature of the fried egg is the fact that it is served on the plate and hence the innovative noun plate-egg. With regard to the recognition of similarity, it is regarded as the human ability to view different objects/phenomena/actions as similar, and, as a result, to categorise and group them together. The areas where recognition of similarity is relevant and, because of that, it contributes to motivating linguistic structure are as follows:

1. Categorisation and generalisation: These processes consist in regarding separate items as being similar, and, as a result, grouping them together as members of the same category, or the same abstract schema. For example, English children in the course of their grammatical development categorise nouns ending in the English suffix $-(e) r$ as agentand instrument-forming suffixes and, consequently, use them to coin innovative nouns denoting agents and instruments, such as brush-er (Clark 1993) from the verb to brush to denote the person brushing tea-leaves out of the sink with her hand, or brake-rs (Clark 1993) from the verb to brake to denote the brakes in the car.

2. Iconicity: This phenomenon consists in perceiving a similarity between the phenomena in conceived reality and the linguistic expressions denoting them. A mechanism of this kind may be observed on the basis of English-speaking children coining innovative compounds in which the first element always distinguishes a particular item from other items, whereas the second element puts the item in question within a certain class. ${ }^{8}$ For example, in the case of the compound boy-lion, its first element lion places the concept expressed within the class of lions, whereas its second element boy distinguishes it from other lions belonging to the same class, such as girl-lions, mummy-lions, etc. Thus, the form of the compound reflects the speaker's cognitive set-up. ${ }^{9}$

The next type of motivation targeted here is defined as communicative motivation. Since the main purpose of language is communication, there is a strong tendency to make communicative acts economical and perspicuous (see, e.g., Grice 1975, Kleparski 1983). Grice (1975) has formulated the following two maxims: Be perspicuous and Avoid ambiguity and vagueness. Thus, the content of the message should be presented with clarity and it should also be coded in such a way that a hearer is capable of interpreting it with minimal processing effort. The long-recognised principle of economy is well

\footnotetext{
${ }^{7}$ In the process of grammatical development phonological salience also plays an extremely important role (see Slobin 1973).

${ }^{8}$ This mechanism was first described by the Polish linguist Rozwadowski (1903), and we shall discuss it in greater detail in one of the sections below.

${ }^{9}$ At this point it should be stressed that, in the light of the cognitive views on the nature of language, there exists a strong relationship between the language and the speaker's cognitive set-up, which means that linguistic conceptualisation is different in different languages (see, e.g., Tabakowska 2001). Consequently, children acquiring their mother tongue build the conceptual network between the entities of their native language relying on the categories typical of this language (Choi and Bowerman 1991). Thus, English-speaking children make use of the modifier + head pattern in the formation of innovative compounds, as in English modifier comes first and head second. Note, however, that it would interesting to study the language in which the head comes second and the modifier comes first and check whether this tendency is reflected in the process of the formation of innovative compounds.
}

Odisea, $\mathrm{n}^{\circ} 7$, ISSN 1578-3820, 2006, 103-117 
conspicuous in the process of the coinage formation in children's speech, as they are much more economical than their adult counterparts. For example, the coinage bear-hat is more economical than its adult equivalent, i.e. 'the hat that looks like a bear', and it can easily be decoded. All in all, we maintain that the child language is characterised not only by the economy of decoding but also by the economy of encoding.

Lastly, it should be emphasised that motivation is a multi-factorial phenomenon, which means that a linguistic unit may be motivated by several factors, or that these factors may compete with each other. As far as the process of the formation of coinages is concerned, one observes that both the co-operation and competition of several motivational factors are at work. First of all, in the case of the formation of the majority of lexical innovation it is plain to observe that several motivational factors have been in operation. For example, when we consider the coinage presser (Clark 1993) from the verb to press to denote 'a button that has to be pressed in order to let water run out', we may come to the obvious conclusion that it is:

1. Ecologically motivated: the coinage fills the niche in the child's linguistic system.

2. Perceptually motivated: the coinage makes use of the idea of the cognitive salience (the child's attention has been drawn to the fact that the most conspicuous feature of this particular button is that it is used by being pressed), and iconicity (the linguistic form exhibits similarity with the phenomenon existing in reality, i.e. the noun has been derived from the verb denoting its actual use).

3. Economically motivated: the coinage expresses the concept it stands for very synthetically.

\subsection{Motivation in the formation of innovative nouns}

Similar observations may be made with respect to the vast majority of coinages quoted in this paper, i.e. the formation of most of the coinages is motivated by several factors: ecological, perceptual and economical ones. On the other hand, one notices that sometimes motivational principles seem to compete with each other. According to Panther and Radden (2004), a prime example of this competition is the conflict between economical and isomorphic motivation discussed by Croft (1990: 192). When it comes to the lexicon, "the principle of economy motivates a minimal vocabulary, while the principle of isomorphism requires a distinct word for every distinct concept" (Radden \& Panther 2004: 31). When we consider children's lexicon, it appears that the principle of isomorphism overrides the principle of economy. Our data clearly shows that children come up with lexical innovations for every word that expresses a distinct concept. For example, one of the Polish children studied for the purposes of this analysis has coined three innovative nouns to denote a construction worker:

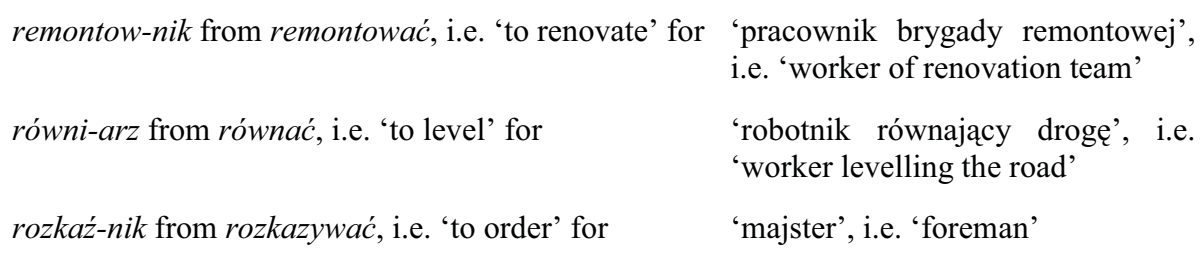

Odisea, $\mathrm{n}^{\circ}$ 7, ISSN 1578-3820, 2006, 103-117 
Likewise, one of the English-speaking children studied by Clark (1993: 99) has formed three innovative nouns to name three different kinds of a truck, that is:

$$
\begin{array}{ll}
\text { 1. a car-truck } & \text { for 'a truck carrying cars' } \\
\text { 2. a cow-truck } & \text { for 'a truck carrying cows' } \\
\text { 3. a shovel-truck } & \text { for 'a truck carrying shovels' }
\end{array}
$$

In our view, the reason for the priority of isomorphism over economy results from the fact that -generally speaking-young children are primarily concerned with and are guided by the here and now principle. Because of that, they associate every particular situation with one situation-specific lexeme. Therefore, the truck carrying cars becomes a car-truck while the truck carrying cows becomes a cow-truck, etc. In the initial period of their linguistic and cognitive development children are unable to generalise about word meanings. A similar finding was made by Clark (1993), who has noticed that before the child masters a particular lexical item, his language is characterised by the so called underextensions, i.e. using a particular word in a very narrow context. For example, the lexeme horse may first be used to denote only toys not real animals. Hence, the high degree of lexical isomorphism in the child language.

On the whole, irrespective of the fact whether motivational factors co-operate or compete with each other, it is metonymy that may be said to play a key role in the formation of neologisms. As Langacker (2000: 199) puts it: "Metonymy allows an efficient reconciliation of two conflicting factors: the need to be accurate, i.e. of being sure that the addressee's attention is directed to the target; and our natural inclination to think and talk explicitly about those entities that have the greatest cognitive salience for us". In what follows an attempt will be made to find and formulate partial evidence for the above statement. We will analyse the role of metonymy in the formation of innovative nouns in English, also providing also some relevant examples from the Polish language to support our argument. The main reason for choosing nouns to be targeted in our analysis is that in any language of the world the class of nouns constitutes the largest percentage of all coinages created by children because labels for objects and -in particular concrete objects- occur most frequently in their speech (Chmura-Klekotowa 1971, Clark 1987).

\subsection{Metonymical motivation in the formation of innovative compounds}

As far as the early period of linguistic development of English-speaking children is concerned, compounding is the most productive morphological operation for coining new nouns (Szymanek 1998, Clark 1987). Compounds produced by children can be divided into root compounds formed from two or more nouns, as in house-key and synthetic compounds formed from one or two nouns combined with a verb, e.g. push-chair (Clark 1993). As will be observed below, almost all the innovative nouns from our data (apart from the last example) are root compounds:

Odisea, $\mathrm{n}^{\circ}$ 7, ISSN 1578-3820, 2006, 103-117 


metonymical compound
bear-hat
clown-boy
bear-son
baby-elephant
baby-bottle
farmers-market
daddy-seed
crumb-catcher
mama-bunny
Ringo grocery
boy-lion
bobo-tea
water-boat
pee-pee cup

\author{
adult counterpart \\ 'the bear that looks like a hat' \\ 'the boy who is a clown' \\ 'the son who is a \\ 'the elephant that is a baby' \\ 'the bottle meant for babies' \\ 'the market meant for farmers' \\ 'the seed that is a daddy' \\ 'the object capable of catching crumbs' \\ 'the bunny that is a mama' \\ 'the grocery that belongs to Ringo' \\ 'the lion that is a boy' \\ 'the tea for a baby' \\ 'the boat floating on water' \\ 'the cup meant for peeing'
}

All the above compounds represent motivated linguistic units in which the target, i.e. the form is motivated by the source, i.e. the content. In other words, the idea that the child wants to express has a direct impact on the form of the compound. In an attempt to account for the relationship between the content of the message and its form let us now go onto the role of extra-linguistic motivational factors. All the above compounds exemplify the way in which children code messages they wish to convey. According to Heine (1997), the content of the message should be presented with clarity and ought to be coded in such a way that the hearer can interpret it with minimal processing effort. In other words, economic motivation is of utmost importance. This is the case with the compounds formed by children, e.g. the compound baby-bottle can easily be decoded as 'the bottle meant for/used by the baby', baby-elephant can easily be understood as 'the elephant who is a baby', etc. Fair enough, these compounds are economical because they are much shorter than their adult counterparts. ${ }^{10}$ Economy, however, is not the only driving force in the process of the compounds formation, as it is a representative example of the morphological process in which several motivational factors are involved. Apart from economy, factors of salience and metonymy are evidently at play.

In order to show the way cognitive salience influences the formation of compounds in English let us rely on the phenomenon of apperception first described by Rozwadowski (Rozwadowski 1903, Tabakowska 2004). Cognitive psychology defines apperception as the process in the course of which the attention of the individual gets focused on a single point. All the rest of potentially perceptible elements lingering in the field of our perception are referred to as perceptions. Although the concept of apperception has -only recentlywon widespread popularity with the advent of cognitivism, it was first propounded for linguistics as early as at the beginning of the $20^{\text {th }}$ century by Jan Rozwadowski, one of the most eminent Polish linguists, whose ideas have given rise to the modern cognitive theories

${ }^{10}$ It should be noted, however, that the economy of these coinages has been achieved at the cost of the explicitness of their interpretation, that is, out of context, the meaning of these innovative nouns may turn out to be quite ambiguous. For example, the compound baby-bottle may stand for the bottle meant for the baby, the bottle belonging to the baby, the bottle with the picture of the baby on it, etc. 
of language. Rozwadowski's theory was strongly influenced by Wundt (1900), according to whom the process of perception consists of the ability to distinguish in every word, phrase or sentence the so called identifier and diversifier, where identifier is the identifying element, while diversifier is the distinguishing element. Thus, in the phrase blue dress, the identifier is the element dress, as it classifies the object within the class DRESS, whereas the diversifier is the element blue because it distinguishes this particular dress from other dresses.

According to Rozwadowski (1903), the perception of things and phenomena defined as apperception consists in the perception of the changing reality, accompanied by the relation of new facts to the facts that are already known from previous knowledge and experience. Several modern linguists have made use of the definition of apperception put forward by Rozwadowski. For example, according to Klimkowski (2005), apperception is the manifestation of iconicity and -because of that- we can talk about the so-called apperceptive iconicity because the process of formation of words and phrases mirrors cognitive strategies of encoding their meaning. Klimkowski (2005) makes use of the Rozwadowski's theory for the analysis of the process of the compound formation in English. Among other things, the author observes that -according to the great Polish scholar- the process of the phrase formation comprises two major cognitive strategies:

1. Establishing similarity links between the already existent utterances (and their meanings),

2. Establishing distinction points between the already existent utterances and the new ones.

This amounts to saying that the second element of the compound is always the identifier, as it establishes similarity links between the already existent utterances, i.e., it classifies objects within a certain class:

$$
\begin{array}{ll}
\begin{array}{l}
\text { daddy-seed } \\
\text { crumb-catcher }
\end{array} & \text { this object belongs to the class SEED; } \\
\text { baby-elephant } & \text { this object belongs to the class CATCHER; } \\
\text { this object belongs to the class ELEPHANT }
\end{array}
$$

whereas their first element is the diversifier, as it establishes distinction points between the already existent utterances and the new ones, i.e., it distinguishes these particular objects from other kinds of objects:

$$
\begin{array}{ll}
\begin{array}{l}
\text { daddy-seed } \\
\text { crumb-catcher }
\end{array} & \begin{array}{l}
\text { not e.g. mummy-seed, i.e. this object is daddy not, e.g. mummy, } \\
\text { not e.g.fly-catcher, i.e. the function of this object is to catch } \\
\text { crumbs not, e.g. flies, }
\end{array} \\
\text { baby-elephant } & \text { not e.g.boy-elephant, i.e. this object is a baby not, e.g. a boy }
\end{array}
$$

While analysing the above English compounds one may observe yet another aspect of perceptual motivation, namely iconicity. All these compounds are iconic as their structure reflects cognitive mechanisms adopted by children during their formation. In other words, the relationship between the modifying and classifying element is manifested in the form

Odisea, $\mathrm{n}^{\circ}$ 7, ISSN 1578-3820, 2006, 103-117 
of the compound in which its second part, i.e., identifier represents the concept known from the child's previous knowledge and experience, whereas its initial part, i.e. diversifier is always related to the child's new experience or changing aspect(s) of reality.

No matter how important all the aforementioned motivational factors and conditionings are, they are far from sufficient to account for the process of the formation of innovative nouns. As Langacker (2000: 16) argues, component structures of complex expressions correspond only to certain facets of them. Therefore, we propose that it is the phenomenon of metonymy that plays a crucial role in the formation of compounds. In order to provide evidence for this conjecture let us make use of the concept of the so-called Idealised Cognitive Model (ICM) proposed by Lakoff (1987: 147).

According to Lakoff (1987), conceptual parts of the complex ICM are motivated by language-independent factors, such as salience, economy and metonymy. On the basis of what has been said so far we may conclude that -according to the notion of the ecological niche- first there is an object that needs to be named. Secondly, as Lakoff (1987) maintains, the object is associated with the complex ICM (source) which constitutes the basis for naming the thing (target). Taking the child language into account, it means that, when the child needs to name something, e.g. a bottle of tea meant for a small baby, he faces a wide variety of features of this object to choose from (such as its size, colour, taste, purpose, etc.), with the aim of coming up with its name. Thirdly, language independent factors such as salience, economy and metonymy - lead to the selection of only certain components of the complex ICM to be transformed by the child into an innovative noun in accordance with the word-formation rules prevalent in a given language. ${ }^{11}$ Consequently, the child comes up with a coinage bobo-tea which names only certain selected features of the object in question, and which - at the same time - is capable of evoking the whole ICM by means of a PART FOR WHOLE metonymy. Therefore, we have grounds to forward a claim that metonymy is a primary motivational factor in the compounds formation, as it is applied both for encoding and decoding concepts expressed by children.

Evidently, as shown by -among others- Dirven (1985) and Kleparski (1997, 2004) metonymy plays a crucial role in the development of lexicon not only in the language of children but also from a diachronic point of view. When, for example, with technological advances within a particular society a new 'thing' is introduced, the need arises to name it. As a result, it is very often the case that several names compete before one of them gains the upper hand over the others and before it becomes established as the conventional designation for this particular object. Thus, for instance, in the $19^{\text {th }}$ century English there existed three metonymical competing names used in the sense 'screwdriver', that is screwturner (attested 1831 in the $O E D$ ), turn-screw (attested 1801, 1837 and 1889) and, obviously, screwdriver. Notice that screwturner and turn-screw may be said to select the same conceptual elements from the complex ICM, whereas screwdriver selects slightly different elements of the ICM by means of a PART FOR WHOLE metonymy. Eventually, according to Croft's (2000: 176) first law of propagation natural languages are characterised by the tendency to conventionalise one of the competing vocabulary items at the expense of the others. ${ }^{12}$ It seems that the resolution of this competition is largely a matter of arbitrariness.

\footnotetext{
11 In English it is compounding, whereas in Polish deverbal nominalisation.
}

12 On this issue see, among others, Kleparski (1983, 1997). 


\subsection{Metonymical motivation in the formation of innovative nominalisations}

Returning to the main issue of this paper, let us now analyse the role of metonymy in the process of the innovative noun formation in the course of the second most productive derivational mechanism in English, that is affixation (Clark 1993). According to Clark, suffixed nouns account for 21 per cent of all the innovative nouns formed by children under the age of four, and for 26 per cent of coinages created by children above the age of four. These innovative nouns are created by means of deverbal, denominal and deadjectival nominalization. ${ }^{13}$ Let us now list examples of innovative nouns of this kind from the Clark's corpus (Clark 1993):

$\begin{array}{lll}\begin{array}{l}\text { metonymical } \\ \text { nominalisation }\end{array} & \begin{array}{l}\text { verbal/nominal/ } \\ \text { adjectival base } \\ \text { to cook }\end{array} & \text { symbolic adult term } \\ \text { to tease } & \text { 'a cook' } \\ \text { tease-r } & \text { to press } & \text { 'a person who teases' } \\ \text { press-er } & \text { lock } & \text { 'a button that needs to be pressed' } \\ \text { lock-erto } & \text { to reach } & \text { 'something capable of locking things' } \\ \text { reach-er } & \text { to brush } & \text { 'a person capable of reaching high' } \\ \text { brush-er } & \text { to hide } & \text { 'a person brushing tea-leaves out of the sink' } \\ \text { hide-r } & \text { sharp } & \text { 'a thing used for hiding oneself' } \\ \text { sharp-er } & \text { to brake } & \text { 'a sharpener' } \\ \text { brake-r } & \text { a gun } & \text { 'a brake' } \\ \text { gunn-er } & \text { to hang } & \text { 'a person carrying a gun' } \\ \text { hang-ie }{ }^{14} & & \text { 'a hanging toy' }\end{array}$

According to Chmura-Klekotowa (1967), the source of all the children's neologisms stems from the development of cause and effect thinking of children aged between two and three. This, in turn, entails children's interest in the etymology of newly acquired words. What can be observed on the basis of the above data, is the fact that to children's knowledge every noun is not merely closely related to designatum, but it also must refer to one of the activities that these objects or people are somehow associated with. Hence, all the above nominalisations pertain to:

1. The activities that the agents and instruments engage in, e.g. reacher stands for somebody who is capable of reaching high, and braker $^{15}$ stands for the instrument used for braking,

\footnotetext{
${ }^{13}$ Deverbal nominalization is the most productive way of forming innovative nouns through the process of suffixation (Clark 1993).

14 This particular example comes from our own language corpus.

${ }_{15}$ As far as this metonymical derivative, as well as two others: cooker and locker are concerned, their adult counterparts, i.e. 'a brake', 'a cook' and 'a lock' are iconic as well, as they are considered to represent one of the three subtypes of an icon, namely a morphological metaphor (Galeas 1998). According to the theory of Natural Morphology (Dressler et al. 1987), a morphological metaphor exhibits some kind of parallelism between signans (signifier) and signatum (signified). Thus, all types of morphological conversion are metaphors as they show parallel signantia mapped onto different although morphologically related signata (Galeas 1998: 9). However, it is maintained that a metaphor represents a lower degree of constructional iconicity than e.g. agglutinative affixation because its not characterised by
} 
2. The activities that the objects are meant for, e.g. hider is something that is meant for being used with a view to going into hiding (adult 'an inverted wastepaper basket put over the child's head in order to hide it'),

3. The outcomes of the activities performed on objects, e.g. hangie is something that has been hung (adult 'a hanging toy').

Therefore, one feels entitled to state that all the above coinages are iconic as they exhibit a close resemblance to the objects or people that they denote because they point directly to the functions or features that, in the children's opinion, are the most characteristic of them. Thus, teaser is a person whose cardinal feature is to tease people, gunner is a person whose primary function is to carry a gun, brusher is the person primarily engaged in brushing, etc.

In order to explain cognitive strategies used by children in the process of innovative nouns formation by means of deverbal, denominal or deadjectival nominalization one may rely again on the theory of apperception that has given rise to the notion of salience in modern linguistics. As defined in the foregoing, according to Rozwadowski (1904), apperception consists in relating new facts to the facts that are already known from previous knowledge and experience. The nature of this process ensures that we are able to perceive distinctly only a limited number of elements out of their total amount lingering in the field of our perception. Because of this fact, the word becomes a reflection of merely one idea out of all the ideas that it represents. For Rozwadowski it is the dominant feature that becomes embodied in a particular word. As far as the very process of naming objects is concerned, Rozwadowski claims that it consists of highlighting a single feature out of many features that a given object is characterised by. In more recent terms, such metonymic coinages may be viewed as cases of "[...] perspectivisation, whereby some covertly or overtly present $[. .$.$] value or values come(s) to the forefront, while other values are not only$ backgrounded but, in fact, may be suppressed completely" (Kleparski 1997: 242). It was already noticed by Rozwadowski (1903) that during the process of naming one element of the model is perceived as dominant, i.e., salient, while all the remaining elements are considered to be far less distinctive and hence dormant. Thus, the formation of innovative nouns consists in highlighting this function of the object or the person that children perceive as dominant in the process of naming, e.g.:

presser - the dominant feature of this object is that it is pressed in order to let water run out, not that it is, e.g. round,

locker - the dominant feature of this object is that it is used for locking things or rooms, not that it is, e.g. made of metal.

the morphotactic transparency reflecting analogically semantic compositionality, characteristic of typical constructional icons. Therefore, the three metonymical derivatives: braker, cooker and locker are more iconic than their adult equivalents as, in each case, the addition of the suffix -er reflects the semantic composition of the word.

Odisea, $\mathrm{n}^{\circ}$ 7, ISSN 1578-3820, 2006, 103-117 
In an attempt to account for the process of naming within the framework of Lakoff's (1987) Idealised Cognitive Model, we might say that each coinage both stands for the whole conceptual network associated with it, and evokes the whole conceptual network in spite of the fact that only some of its elements are expressed by a given innovative noun. Therefore, we feel justified in claiming that the nouns analysed in this paper may be labelled as metonymical derivatives. They are metonymical in a sense that the meaning they convey constitutes merely a part of the whole range of meanings that a particular noun conveys. Thus, we may conclude that the nouns targeted here tend to be motivated by the PART FOR WHOLE metonymy. For example, the noun hangie, used in the sense 'a hanging toy' is metonymical in the sense that it expresses merely a fragment of the whole composite concept that the noun denotes. This coinage foregrounds merely one of the characteristic features that a hanging toy has, namely that it has been hung. However, this noun also represents the composite concept by which we should understand its general characteristics, such as the material it is made of, its colour, its shape, its size, etc., that is, it evokes an Idealised Cognitive Model of a hanging toy. Beyond doubt, many of the conceptual features of a hanging toy are backgrounded and not included in the semantics of the coinage. Thus, highlighting and perspectivisation of dominant functions/features/ characteristics of a given object or a person simultaneously entails ignoring and backgrounding those functions and elements that are considered to be less distinctive by children. This leads to metonymically motivated phenomena in the process of wordformation.

As far as Polish innovative nouns are concerned, 90 per cent of them are formed through deverbal nominalization (Chmura-Klekotowa 1967), foregrounding the most prominent features of a given object and backgrounding those considered to be less outstanding. At this point let us present some Polish examples of metonymically motivated innovative nouns from our language corpus:

turla-czka, i.e. 'reel' (made from the verb turlać się, i.e. 'to roll') - the reel's capacity for rolling has been foregrounded, whereas the fact that it can, e.g. be spooled in thread, has been backgrounded,

obcina-czka, i.e. 'hairdresser' (made for the verb obcinać, i.e. 'to cut') - the hairdresser's capacity for cutting hair has been foregrounded, whereas her capability to dye it has been backgrounded.

zasuwa-nka, i.e. 'zip' (made from the verb zasuwać, i.e. 'to do up') - the zip's capacity for doing up things has been foregrounded, whereas the fact that it can, e.g. be made of metal or plastic has been backgrounded.

\section{CONCLUSION}

To recapitulate, to a large extent the development of the lexicon is metonymically motivated both from a synchronic and diachronic perspective. Studying the process of the formation of innovative words one may differentiate several stages. First of all, there

Odisea, $\mathrm{n}^{\circ}$ 7, ISSN 1578-3820, 2006, 103-117 
appears a 'thing' that needs to be named for which there is no appropriate term in the language. Then, because the empty slot in the linguistic system needs to be filled, the 'thing' is set against and associated with the complex ICM (source), which constitutes the basis for naming the thing (target). Next, the process of naming is guided by languageindependent factors, such as salience, economy and metonymy. As a result, by means of a PART FOR WHOLE metonymy only some components of the complex ICM are chosen and named by (a) particular language user(s) in the process of forming a new word. Moreover, a PART FOR WHOLE metonymy enables one to evoke the whole ICM of a given object as well. Therefore, it is considered to be a crucial motivational factor both in encoding and decoding meanings expressed by lexical innovations.

\section{REFERENCES}

Beitel, Dinara A., R. W. Gibbs, \& P. Sanders. 1997. "The embodied approach to the polysemy of the spatial preposition on”. H. CuYCKEns \& B. ZAWADA. Eds. Polysemy in Cognitive Linguistics. Amsterdam/Philadelphia: Benjamins. 242-260.

Chmura-Klekotowa, M. 1967. “Neologizmy słowotwórcze w mowie dzieci”. Poradnik J'zykowy 10: 433-435.

$$
\text { 21: } 99-235 .
$$

1971. "Neologizmy słowotwórcze w mowie dzieci”. Prace Filologiczne

Chol, S. \& M. Bowerman. 1991. "Learning to express motion events in English and Korean: The influence of language-specific lexicalization patterns". Cognition 41: 83-121.

CLARK, E. 1987. "The principle of contrast: A constraint on language acquisition” [in:] B. MAC Whiney, ed. Mechanisms of Language Acquisition. Hillsdale, NJ: Lawrence Erlbaum Associates. 1-33. Press.

1993. The Lexicon in Acquisition. Cambridge: Cambridge University

CRoft, W. 1990. Typology and Universals. Cambridge: Cambridge University Press.

2000. Explaining Language Change: An Evolutionary Approach. Harlow, Essex: Longman.

Dirven, R. 1985. "Metaphor as a basic means for extending the lexicon". W. PAPRotTE and R. DiRVEN. Eds. The Ubiquity of Metaphor: Metaphor in Language and Thought. Amsterdam-Philadelphia: John Benjamins Publishing Company.

Dressler W., M. Willi, O. Panegl and W. Wurzel. 1987. Leitmotifs in Natural Morphology. Amsterdam: John Benjamins.

GeERAERTS, D. 2002. "The interaction of metaphor and metonymy in composite expressions". R. DiRven and R. PöRINGS, eds. Metaphor and Metonymy in Comparison and Contrast, Berlin, New York: Mouton de Gruyter. 435-465. 
GALEAS, G. C. 1998. “Scalar Categorization” http://wjmll.ncl.ac.uk/issue03/crocco.htm

Grice, H. P. 1975. "Logic and conversation". Cole, P. \& Morgan, J. L., eds. Speech Acts (Syntax and Semantics 3), 41-58. New York: Academic Press.

HaImAn, J. 1980. "The iconicity of grammar: Isomorphism and motivation" Language 56: $514-540$.

University Press.

HeINE, B. 1997. Cognitive Foundations of Grammar. New York and Oxford: Oxford University Press.

HiRAGA, M. K. 1994. "Diagrams and metaphors: Iconic aspects in language" Journal of Pragmatics 22, 5-21.

KAnT, I. 2001. Krytyka czystego rozumu. Kęty: Antyk.

KLEPARSKI, G. A. 1983. "Lexical mobility: Some problems of its justification and interpretation”. Kwartalnik Neofilologiczny 30, 3-12.

1997. Theory and Practice of Historical Semantics: The Case of Middle

English and Early Modern English Synonyms of GIRL/YOUNG WOMAN. Lublin: Redakcja Wudawnictw KUL.

. 2004. "CDs petticoats, skirts, tamaras and sheilas: The metonymical rise of lexical categories related to the conceptual category FEMALE HUMAN BEING". Ch. J. KAY and J. SMIтH Categorisation in the History of English. Amsterdam-Philadelphia: John Benjamins Publishing Company.

KLIMKowsкi, K. 2005. "Apperception in compound formation as a manifestation of iconicity". http://home.hum.uUva.nl/iconicity/conferences/2005/2005 abstracts. html

Lakoff, G. 1987. Women, Fire, and Dangerous Things: What Categories Reveal about the Mind. Chicago and London: University of Chicago Press.

Langacker, R. W. 1987. Foundations of Cognitive Grammar. Vol. 1. Theoretical Prerequisites. Stanford, CA: Stanford University Press.

LANGACKer, R. W. 2000. Grammar and Conceptualization. Berlin, New York: Mouton de Gruyter.

RadDen, G. and P. Klaus-Uwe. 2004. "Introduction: Reflections on Motivation". RadDen G. and KLaus-Uwe P. Eds. Studies in Linguistic Motivation (Cognitive Linguistics Research 28), 3-46.

RozwADOwsKi, J. 1903. "Semazyologia czyli nauka o rozwoju znaczeń wyrazów. Jej stan obecny, zasady i zadania". Eos, 17-111.

Saussure, F. de. 1916/1959. Course in General Linguistics. New York, Toronto, London: McGraw-Hill. 
SLOBIN, D. 1973. "Cognitive prerequisites for the acquisition of grammar". D. SLOBIN and Ch. Ferguson, eds. Studies of Child Language Development 173-208. New York: Holt, Rienhart and Winston.

SzYMANEK, B. 1998. Introduction to Morphological Analysis. Warszawa: Wydawnictwo Naukowe PWN.

TавакоwsKa, E. 2001. Kognitywne podstawy języka i językoznawstwa. Kraków: Universitas.

2004. Kognitywizm po polsku: wczoraj i dziś. Kraków: Universitas.

WunDT, W. 1900. Volkerpsychologie; Eine Untersuchung der Enticklungsgesteze von Sprache. Lipsk: Kröner. Hutchinson Encyclopaedia. 2000. http://www.tiscali. co.uk/ reference/encyclopaedia/hutchinson. 